\title{
Food safety and the informal milk supply chain in Kenya
}

\author{
Hasibi Zavala Nacul ${ }^{1 *}$ (iD and Cesar Revoredo-Giha ${ }^{2}$
}

\begin{abstract}
Background: Informal dairy supply chains are important in Sub-Saharan Africa, both in terms of employment and nutrition for poor population. Their safety has been debated in the literature, with those in favour to their legalisation, arguing that boiling milk reduces sanitary risks for its consumption and the nutritional impact offsets those possible risks. While, the opposing side, highlighting that boiling milk does not eliminate all the contaminants that are found, and the long term sanitary and health impact should be a major concern for regulatory enforcement.

The purpose of this case study, which focuses on food safety along a dairy supply chain in Kenya, the largest milk producer in Africa, is twofold: first, to review the different issues on food safety when consuming raw milk, and second, to extract lessons from a case study that follows an informal supply chain that operates in rural, peri-urban and urban areas in the Kiambu and Muranga counties in Kenya. This case study was based on semi-structure interviews to 29 stakeholders and participants of an informal dairy supply chain carried out in April-May 2019. The purpose of the interviews was to provide insights of the hurdles and food safety risks surrounding everyday activities of milk handlers.

Results: The results indicate that the informal dairy sector is associated with low-quality milk and food safety risks. These assumptions are linked to several factors such as lack of contact and control from the sanitary and health authorities, lack of awareness regarding milk safety from both consumers and the different supply chain participants; and the poor operating conditions the informal market has. In addition, other aspects were the overall lack of hygiene, accountability, and infrastructure in the entire supply chain.
\end{abstract}

Conclusions: In conclusion, greater focus should be put on improving food safety quality along the chain (e.g., through ensuring the application of Good Handling Practices like the use of food grade containers and the introduction control points). The reform of Kenya's informal dairy market must focus on training to improve and increase the hygiene and safety practices of the informal operators to reduce the information gap that divides formal from informal.

Keywords: Informal milk supply chains, Food safety, Kenya, Sub-Saharan Africa

\section{Introduction}

Kenya, located in Sub-Saharan Africa (SSA), suffers from food insecurity due to several intertwined reasons. According to the regional overview of the FAO, three major drivers affecting food security are climate change, conflict and economic slowdowns [12]. In 2019, a delayed

*Correspondence: hazana.qa@gmail.com

${ }^{1}$ Independent Food Security Consultant, Mexico City, Mexico

Full list of author information is available at the end of the article rainy season led to water scarcity. This situation caused food shortages limiting household food availability, decreasing dietary diversity, and amplifying malnutrition problems (FEWS [13]. The most vulnerable households in crisis reduced their meals to one per day with maize, beans, oil, and sugar as the key staples. This cluster of situations (environmental, social, and economic) worsens the general status of food security in the country (FEWS [13]. original author(s) and the source, provide a link to the Creative Commons licence, and indicate if changes were made. The images or other third party material in this article are included in the article's Creative Commons licence, unless indicated otherwise in a credit line to the material. If material is not included in the article's Creative Commons licence and your intended use is not permitted by statutory regulation or exceeds the permitted use, you will need to obtain permission directly from the copyright holder. To view a copy of this licence, visit http://creativecommons.org/licenses/by/4.0/. The Creative Commons Public Domain Dedication waiver (http://creativeco mmons.org/publicdomain/zero/1.0/) applies to the data made available in this article, unless otherwise stated in a credit line to the data. 
Agriculture in Kenya is an important economic pillar that contributes to 24 per cent of the Gross Domestic Product (GDP). Within the agricultural GDP, Kiambi et al. [20] who studied the Nairobi informal sector area, indicated that the dairy sector represents 12 per cent of the agricultural GDP and is known to be one of the major sources of nutritional security, especially for lowerincome groups. Moreover, the informal sector represents 70 per cent of the dairy's jobs and 86 per cent of the milk market [16]. The informal sector involves those actors that participate in the supply chain but are not registered or licenced to operate [21].

The legal framework of the Kenyan dairy sector was reformed at the beginning of 2004. The purpose of the reform was focused on the economic importance that the informal sector (i.e., those trading in raw milk) had for smallholders producers. It fomented the revision of policies to decriminalize their activities and encourage their registration with the respective authorities [16]. Before then, milk regulation was focused on large-scale production that only represented the minority of the dairy sector. However, the reform was accused of being a pro-poor policy that empowered more the informal sector rather than focusing on the development of the formal one [15]. In recent years, due to lobbying power from the private sector, there has been pressure to go back to the pre-2004 regulatory system that illegalizes the trade of raw milk [29], which is associated with low-quality milk and food safety risks.

It should be noted that in contrast with dairy supply chains in developed countries (e.g., Antonioli \& Santeramo [2] and their cited literature) and despite their importance in continents such as Africa, information about the functioning of informal dairy supply chains is limited, in particular, when considering a detailed food safety point of view. From the food safety position, the case of informal chains is interesting, because it differs from cases of food fraud such as the melamine contaminated infant formula in China (e.g., [43] as they operate openly and consumers knowingly purchase the raw milk (i.e., there is no asymmetric information).

Hence, the purpose of this study, which focuses mainly on the Kenyan counties of Kiambu and Muranga, is to present a picture of all the links involved in the informal milk food chain and its food safety issues (note that aspects related to supply chain management, e.g., trust or business performance as in Susanty et al. [39] were not considered). Some of the studied factors were: contact and control with the sanitary and health authorities, awareness regarding milk safety from both consumers and the different supply chain participants, and the general operating conditions of the informal market. In addition, other aspects revised were hygiene, accountability, and infrastructure of the entire supply chain.
The importance of this case study has been to review all types of contaminants present in raw milk and that represent public health risks. In addition, the value of the results is meaningful, because SSA countries see the reform of the Kenyan dairy sector as an example and a way to progress their sectors. If the SSA countries want to legalise their informal sector they need to consider all the aspects, benefits, and hurdles that this sector provides. In addition, they also need to examine the challenges introduced by the Kenyan reform and its compliance. For example, criminalizing the informal sector and ostracizing it from the aid of the sanitary authorities [21].

The structure of this paper is as follows: It starts with a review of food safety risks of consuming raw or unpasteurized milk, proceeding with a literature review on the dairy sector in Kenya. Afterwards, the methodology used in the paper is presented: i.e., methods and data, continued by the results, discussion and finally the conclusions.

\section{Food safety risks of consuming raw or unpasteurized milk}

Raw milk quality and safety depend on several factors, generally, they can be derived from having and maintaining good agricultural practices, good veterinarian practices and good hygienic and handling practices [37]. Healthy milk comes from healthy cows, but milk quality can easily decrease if the proper conditions are not kept while milking and handling the product.

In the case of Kenya, raw milk is rarely consumed like so since it is boiled by the majority of the consumers (approximately 96 per cent) [34]. It is well documented that pasteurization ${ }^{1}$ helps reduce mainly the microbiological risks associated with milk consumption [26, 33]. However, boiling milk at home without maintaining a standardized temperature during a define period of time is not equivalent to pasteurizing. In addition, other types of contaminants are thermostable and remain mostly unaltered. Therefore, the consumption of low quality, unpasteurized and unsafe boiled milk could pose a high public health risk.

\section{Microbiological risks}

Milk is a rich substrate. Its physicochemical composition and water content make it prone to the proliferation of spoilage bacteria and pathogens. High milk quality is associated with a low number of somatic cells and a low bacteria count. It is free of antibiotic

\footnotetext{
1 "Pasteurization of milk is defined as the heating of every particle of milk to a standardized temperature for a defined period of time without allowing recontamination of that milk or milk product during the process" [26].
} 
residues and human pathogens [33]. Fresh milk from a healthy cow has a low microbial load (less than 1000 per $\mathrm{mL}$ ). When milk is not handled properly and is stored at room temperature, rather than in refrigerated conditions, this load can increase 100 fold [38].

Raw milk can be a vehicle of transmission of a broad range of human pathogens. According to Oliver et al. [33], the most commonly reported pathogens associated with milk are Listeria and Salmonella. However, other zoonotic pathogens that are present in the cattle gastrointestinal system can also contaminate the milk if the correct practices are not implemented like Campylobacter, Yersinia, Shiga-toxin-producing Escherichia coli (STEC) or Verocytotoxin-producing Escherichia coli (VTEC) and Staphylococcus aureus [4]. Another known foodborne pathogen is Bacillus cereus, a spore-forming, well-adapted and highly resistant contaminant that can also produce biofilms $[7,14]$. Biofilms are surface based microbial communities that are used as a survival mechanism by different bacteria to adapt to extreme environmental conditions like heat, freezing, etc. [14].

Important pathogens, particularly relevant in the case of raw milk are Coxiella burnetii, Mycobacterium tuberculosis, Mycobacterium bovis, that are the infectious agents causing illnesses like brucellosis, tuberculosis, typhoid, paratyphoid and diphtheria [4, 38, 42]. Most of the pathogens can cause gastrointestinal problems.

In the case of Kenya, the microbiological quality of milk especially of that sold in the informal market is relevant, since the limited available studies done in different regions of the country have established that milk does not comply with the standards set by the Kenyan Bureau of Standards (KEBS) [34, 42] and smallholder farmers tend to have low knowledge level and negative attitudes to milk quality standards [31]. Milk borne diseases are directly associated with the consumption of low-quality milk. Therefore, the higher consumption of unpasteurized milk can lead to higher chances of a foodborne milk-related disease outbreak [33, 37].

As discussed before, milk in Kenya is mostly boiled before consumption. It is vital to highlight that even if milk undergoes through some thermal treatment, there are still health risks posed to the consumers. For instance the prevalence of thermoduric bacteria and the presence of spores [7]. In addition, if the bacteria load is too high boiling milk, without the correct standardized times and temperatures, might not be sufficient to eliminate them [6]. There are other non-microbiological heat resistant contaminants that can affect milk safety.

\section{Chemical risks}

There are three main sources of chemical contamination in milk: first, toxins from bacteria and moulds; second, residues from antimicrobial agents like antibiotics; and third, the use of adulterants [33, 35, 38]. The study of these chemical contaminants is particularly relevant in the case of Kenya since most of them cannot be removed or eliminated via thermal treatment. Nyokabi et al. [31], mentioned that smallholder farmers tend to participate in the informal system and that especially those with low knowledge levels have negative attitudes towards respecting antibiotics treatment withdrawal. They assume antibiotics are diluted in the bulking tanks or destroyed when the milk is boiled, making antimicrobial presence a recurring problem.

\section{Enterotoxins}

Enterotoxins are produced by certain bacteria. This type of toxins are harmful substances associated with food borne illness that affect the digestive system causing symptoms such as cramps, nausea, emesis, or diarrhoea [7]. The most common enterotoxins associated with milk come from Staphylococcus aureus known as staphylococcal enterotoxins. These enterotoxins are responsible for foodborne outbreaks across the world and are among the most common causes of gastroenteritis [11,33]. Oliver et al. [33], mentioned some outbreaks associated to the consumption of raw milk in the United States for example in 2008 in the state of California, where 16 cases were confirmed with Campylobacter spp.

These microorganisms can produce their toxins in various stages along the production chain, particularly, during unchill storage. Even if Staphylococcus aureus is destroyed with thermal treatment its toxins endures [4]. Another toxin-producing microorganism is Bacillus cereus. This spore-forming microorganism can tolerate heat treatment and remain dormant and capable of producing toxins. Its toxins are mainly associated with gastrointestinal problems like emesis and diarrhoea $[7,14]$.

\section{Aflatoxins}

Aflatoxins are heat resistant and are regarded as the most important mycotoxin affecting human food and animal feed. Aflatoxicosis is associated with areas, where there are climate stressors on plants (like droughts) and poverty [10]. The most common aflatoxin in milk is aflatoxin M1 (AFM1). AFM1 is a metabolite produced from aflatoxin B1 (AFB1) and excreted through milk or urine. AFB1 is produced mainly by Aspergillus flavus and Aspergillus parasiticus and it enters the cow's diet via contaminated feed [24]. AFB1 has the highest degree of toxicity and is even classified in group 1 of human carcinogens by the 
International Agency on Cancer research. Both aflatoxins are considered teratogenic (affect the development of the embryo), hepatocarcinogenic (produce liver cancer) and mutagenic (cause damage in genetic material) [3].

Aflatoxigenic fungi contaminate the crop preharvest primarily when the plants have adverse growing conditions; and then aflatoxins can be produced pre and postharvest, especially when the grains are stored in poor conditions, where the fungus has a warm temperature and high moisture to develop [10].

\section{Antimicrobial and drug residues}

Antimicrobial agents residues like sulfamethazine, gentamicin, tetracyclines are associated with public risk concerns mainly linked to allergic reactions that can vary in severity from skin rashes to anaphylaxis [17]. In addition, the consumption of antimicrobial agents with regularity can lead to drug resistance affecting especially the population with immunodeficiencies for instance children, pregnant women and elderly people, causing long term effects on population health and disease control [35, 38].

According to the findings of Omore et al. [34], most of the milk samples taken from the informal market from urban and rural Nairobi and Nakuru were contaminated with drug residues which limits were above the maximum level recommended by the international food standards. In addition, Ondieki et al. [35], reported the same kind of positive results for the region of Lamu. Kang'ethe et al. [17], also reported a high prevalence of antibiotic and antibacterial residues in the milk samples from contrasting markets like Nairobi, Nakuru and Narok. Moreover, according to these studies, this risk is associated with the common practice of using unauthorized animal and health service providers.

\section{Adulterants}

In the case of adulteration, some common adulterants are water to augment the volume or the use of salts or urea to increment the solid content, these practices lower the nutritional value and can be a source of cross-contamination in the finished product [35]. Other adulterants include colourants to cover any quality deviation, preservatives like chlorine and hydrogen peroxidase to extend the shelf life of the mixture of low-quality milk sourced from other animals. Milk adulteration or fraud is not only an economic issue but is also linked with health problems, like the use of urea can lead to renal problems for the consumers [5] and increasing microbial risk and pathogenic presence.

\section{Physical contamination}

Hygienic milk handling and good farm practices are two areas that need to be improved in the dairy market in
Kenya especially for the smallholder. Milk handling and good manufacturing practices have also a key role in maintaining milk safety. The use of the proper tools and the correct storing and packaging materials help reduce the presence of foreign objects in the milk ready to be consumed [23]. The most common material used in the informal market in Kenya is cheap plastic. The recommended options are food-grade plastic or aluminium [31, 34]. Physical hazards or foreign matter can cause harm that ranges from lacerations inside the mouth, throat, and gastrointestinal system to choking and asphyxiating. Foreign matter can also lead to cross-contamination or be a vector for microorganism development [25].

\section{The dairy sector in Kenya}

Kenya's milk sector contributes significantly to the livelihood of many households. As pointed out by Thorpe et al. [40] and Kaitibie et al. [16]. According to Kiambi et al.[21], the sector represents the source of livelihood for more than 2.6 million people and has an economic value of 230 million US dollars. The history of the Kenyan milk sector can be divided into four periods. First, the pre-independence period (before 1963), where dairy was mainly led by large scale colonialists and export oriented. Second, the after-independence I period (1967-1978) when the policy to include indigenous Kenyans was created. Third, the after-independence II period (19792004) when the sector suffered from bad management decisions and corruption that led to the development and propagation of the illegal informal sector. Fourth, the current administration (2004 onward) with the inclusion of a pro-poor policy that legalizes the informal market and decriminalizes the activities of the smallholder producers. However, population growth, urbanization and the rise in the demand keeps the sector developing and evolving [21].

The informal sector that represents 70 per cent of the dairy's jobs and 86 per cent of the milk market [16]. It is composed of all those actors that participate in this food system but are not registered or do not have a licence to operate [21]. The formal sector is mainly dominated by a few top processors. Brookside Dairy Limited (Brookside) and New Kenya Co-operative Creameries LTD (New KCC) being the most important [40]. However, SSA dairy and Kenya have become, in recent years, a new frontier of expansion to international companies such as Danone, Nestle and Unilever. For instance, in 2014, Danone bought 40 per cent of Brookside stakes planning an aggressive market takeover [41]. The interest of private investors has had regulatory consequences. In 2018, a new regulation was proposed to make the trade of raw milk illegal again and to strengthen the role of processors 


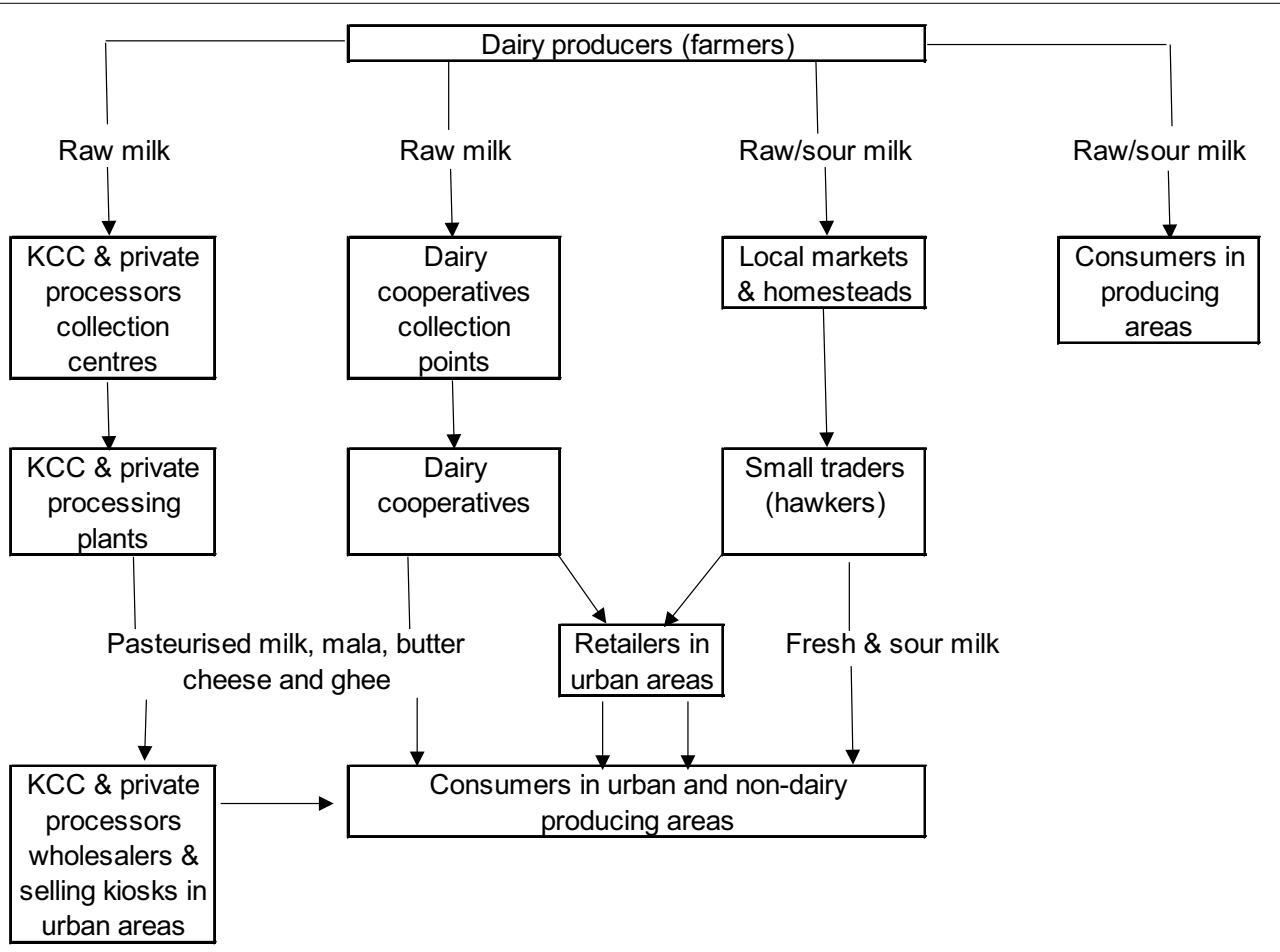

Fig. 1 Milk marketing channels in Kenya. Source: [30]

and licences participants consequently going back to a 2004 panorama [29].

In this section, the different parts of the supply chain will be presented to provide an updated picture of the system and the elements involved in it. Special focus will be given to the informal sector since most of the milk sold in the country follows through this path.

Milk comes mainly from cattle (84 per cent), camels (12 per cent) and goats (4 per cent). Milk cattle is mainly constituted of improved exotic breeds and their crosses and indigenous zebu. While the improved breeds (Friesian-Holstein, Ayrshire, Guernsey, Jersey) provide most of the milk, the zebu is better adapted to the environment and plays a key role in the more arid parts of the country [28]. Whole fresh cow milk production has increased since the $90 \mathrm{~s}$ going from 1.9 million tonnes in 1996 to 3.5 million tonnes in 2017: with an average yield of 6129 hectograms per animal for the last 10 years [12]. It should be noted that production is affected by climatic alterations like prolonged droughts, the rise in production costs and social problems like the displacement of farmers from high productive agricultural areas [19].

Milk production systems can be divided into two main categories: high or market production and arid and semiarid systems [8]. Market production is mainly located in high altitude regions with a humid production system, $60 \%$ of the national production is located in the central districts of Rift Valley and Central province [28]. This system is dominated by smallholder dairy farms that have mainly exotic-local breed crosses and a cut and carry feeding system. On the other hand, the arid/ semiarid system has a pastoralist subsistence production with an extensive grazing feeding system. This type of dairying is located in the north and south Rift Valley, eastern and coast regions $[8,28]$.

Kenya's dairy value chain is mainly driven by small scale actors that operate independently but that are highly interconnected. This sector has a wide range of participants from authorities like the Kenya Dairy Board (KDB) and the Veterinary board to farmers of all sizes, dairy cooperatives, traders, hawkers, processing companies, cooling centres, retailers, etc. that are continuously interacting and developing their channels, coordination mechanisms and rules [20,21].

Milk in Kenya flows through two main types of markets: the formal which sells mainly pasteurized milk and the informal that sells mostly raw milk (Fig. 1). The formal market is operated by dairy enterprises that have a license, a well-defined legal framework, fixed facilities and are inspected regularly. Some key participants are processing companies and cooperatives [20, 32]. This sector relies mainly on formal agreements between large-scale producers and processors. The price setting is fixed by the processors with a lack of transparency or 
participation from the farmer [32]. By contrast, the informal dairy market is generally characterized for having limited infrastructure, with precarious access to clean water, electricity, sanitation, and refrigeration facilities, with no adherence to safety regulations. In addition, they operate without a licence, have limited support from the public sector and are alienated from participating in the formal market. This sector depends on transitions done on the spot, lacking formal contracts and contractual engagement $[1,32]$.

Some of the main drivers for actors to participate in the informal market are: it is considered as an easy business with no barriers to entry, there is always a demand for unpackage raw milk and milk process can be set on the spot [1,32]. Kiambi et al. [21], mentioned that there are also many barriers that smallholders face and demotivated them to participate in the formal sector, like the lack of coherence between policy and practice, creating a fragmented regulatory system that adds complexity and additional operational costs without an appreciable benefit.

On a positive level, informal milk markets can be considered as a source of jobs for a more unprivileged sector of the population that needs access to cheap milk and money. In addition, farmers can have an unrestricted choice regarding whom to sell so they can access better prices when compared to the formal market [30]. Adversely, this market has created some challenges for the public sector, mainly related to quality control and food safety, e.g., milk that is rejected by the formal market can be sold here at a lower price without any verification.

According to Alonso et al. [1], informal traders consider that licensing can be costly, and the regulations are complex to understand hampering their compliance. In the light of this situation, the KDB with the help of the KEBS and the sanitary authority has implemented a series of training programs focusing on the importance of hygiene practices, introducing simple quality tests and assessing regulation compliance [1]. Regardless, Kiambi et al. [20], mentions that licensing and participating in the formal market is not a guarantee of food safety, since many established and trained traders continue to operate with similar unrecommended practices mirroring those of the informal sector.

Before 2004, the milk regulation was focused on largescale production that only represented the minority of the dairy sector. However, there was a change largely due to the creation and implementation of the Smallholder Dairy Project (SDP) that focused on the sustainable development of this type of producer. SDP had two main phases: the first (1997-2000), highlighted the critical role that the informal market had on the livelihood of people and how being neglected by the public sector led to public risk hazards, this phase also involved improving farming practices, bringing innovation into handling and transport. The second phase (2000-2005) focused on understanding the importance of the sector and fomenting the revision of policies to decriminalize their activities [16]. However, this was not an easy transaction and the country had mediatic "Milk wars" and was accused of having pro-poor policies that empowered more the informal sector rather than focusing on the development of the formal one [15].

The main policy change was the Legal notice 102 that expanded the types of licenses that could exist and reestablished the licence application procedures. These licenses try to ensure better quality for the consumers by forcing traders to meet hygienic conditions and comply with sanitation and health standards. Thanks to this change, KDB was able to interact more freely with this market, start training and licencing programs. In addition, the relationships between smallholders and health regulators improved by reducing harassment from the authority and disincentivising bribing [15, 16]. Some of the regulations that affect the sector are the Dairy Industry Act CAP 366 that gives power to the KDB as the authority in charge of licencing and supervising milk handling, quality and safety along with the food system; the Public Health Act, Chapter (CAP) 242, the Drugs and Chemical Substance Act, CAP 254, and the Meat Control Act, CAP 354 [21]. Furthermore, KEBS has also set a series of programs to aid in the compliance of standards. The standards are mainly divided into 4 types: compositional, microbiological, antimicrobial residues and aflatoxins. The main ones that address milk quality and safety (till 2019) are shown in Table 1.

\section{Empirical analysis}

The purpose of this section is to provide an overview of the case study done in the Kiambu and Muranga counties in Kenya. This case study had the objective to observe closely how the dairy supply chain operates in rural, peri-urban and urban areas. It aims to contribute to the development of a holistic view of how the informal market functions while providing meaningful insights into the hurdlers and food safety risks surrounding everyday activities of milk handlers by conducting a series of interviews with different participants and stakeholders of the sector.

\section{Methods}

The case study protocol was designed using the recommendations provided by Bryman [9] and Yin [44]. The case study protocol included the overview of the project, the field procedures, the questions chosen and the guide for the report. The main reason for deciding to 
Table 1 Main standards for milk active to the 2019

\begin{tabular}{|c|c|}
\hline Standard & Name \\
\hline KS 12-1\&2:1976 & $\begin{array}{l}\text { Determination of fat content in liquid milk_Part 1: Rose Gottlieb method (Reference method)__Part 2: Gerber method (Not for } \\
\text { reference) }\end{array}$ \\
\hline KS 13-1\&2:1976 & Determination of total solids in milk_Part 1: Gravimetric method_Part 2: Density method. / Milk and milk products \\
\hline KS ISO 4833-1:2013 & $\begin{array}{l}\text { Microbiology of the food chain-Horizontal method for the enumeration of microorganisms Part } 1 \text { : Colony count at } 30{ }^{\circ} \mathrm{C} \text { by the } \\
\text { pour plate technique. / Milk and milk products }\end{array}$ \\
\hline KS ISO 4833-2:2013 & $\begin{array}{l}\text { Microbiology of the food chain-Horizontal method for the enumeration of microorganisms Part } 2 \text { : Colony count at } 30^{\circ} \mathrm{C} \text { by the } \\
\text { surface plating technique. / Milk and milk products }\end{array}$ \\
\hline KS 33-1\&2:1977 & $\begin{array}{l}\text { Determination of the presence of preservatives and pesticide residues in dairy products_-Part 1: Determination of the presence of } \\
\text { preservatives in milk_-Part 2: Determination of pesticide residues in da / Veterinary drug Residues and Antimicrobial Resistance in } \\
\text { Food }\end{array}$ \\
\hline KS 37:1977 & Code of hygienic practices in the dairy industry for milk carriers. / Milk and milk products \\
\hline
\end{tabular}

Source: KEBS 2019 [18]

use this method was that it allows to retain a wholesome approach to the current situation of the dairy system in Kenya, especially of the informal sector. The semi-structured questionnaire developed (Annex) for the interviews focussed on covering general topics that were transversal throughout the entire supply system (e.g., pricing, quality keeping and common food safety problems). Then, they include differentiated sections for each type of participant and their faced challenges. The interviewed included various actors of the supply chain from farmers of different production sizes to cooling tanks operators and administrators, to the consumers and the authorities.

These interviews were not based on statistical principles, but they were convenience sampling focused on the desire to collect as much information as possible given the budget and time constraints. Semi-structured interviews and informal discussions were used to engage with the participants, while they were doing their routine milk operations.

Since the focus of the study was the informal market, most of the interviewed were without any prior appointment. All the information was written down considering recording was not an option due to the setting being too noisy in most of the cases. Word of mouth was a helpful way to find participants in the region and to connect with the different links of the supply chain.

The case study team had four members: a chauffeur that was acquainted with the region and three masters' students, 2 of them from the Jomo Kenyatta University of Agriculture and Technology (JKUAT) that help translate some of the responses and made the people interviewed more comfortable, and the main author.

Limitations of the study are that some participants especially those from the informal market did not feel comfortable sharing personal information or answering some key questions. For these cases, that information was left as a blank and an informal approach was taken to try to extract other relevant data. In addition, since many people interviewed did not speak English, the information presented also relies on the translation made in situ by the master students previously mentioned. Another important limitation is that people from the peri-urban and rural areas were open and willing to participate in the interviews for free, while the people encountered in the urban Nairobi, reject answering the questions if a monetary compensation was not included. For this reason, this study does not include interviews from the informal market in Nairobi city.

Note that the purpose of the case study was to pursue an in-depth study of an informal dairy supply chain. There is no information about the population of informal dairy chains to apply a statistical approach on the selection. Therefore, the focus consisted of applying the following rules: (1) Select a case that aligns with our topic of research (an informal dairy supply chain); (2) See if the case study has a "universal" applicability (based on other work done in Sub-Saharan Africa, e.g., Malawi, we chose to work on peri-urban informal dairy supply chains); (3) Ensure the case study is relevant in today's date (based on our knowledge of other informal supply chains in other countries, the characteristics of the selected chain were relevant to understand the case); (4) Choose a single case that functions as a sample (our focus was to pick a case that represented an informal supply chain and not whether it was representation of different areas of the country, e.g., rural, peri-urban and urban).

The case study area is shown in Fig. 2, with Kiambi county indicated in red and Murang'a in purple. Kiambu County is in the central region of Kenya. This county has a high population growth rate of $2.81 \%$ and an influx of people working in Nairobi but living here. The county is ongoing industrial development and a growing urban population [22]. Murang'a County is bordered to the south by Kiambu. The county has 6 agro-ecological zones, 


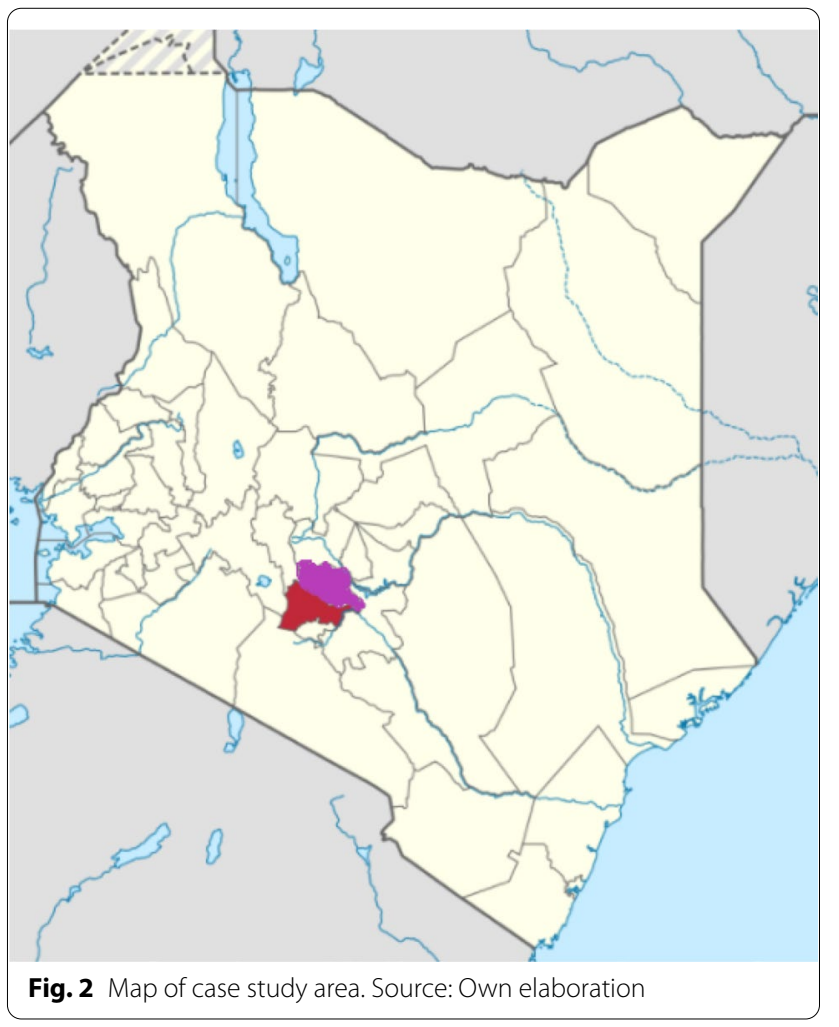

where tea, forestry and tourism are the most important activities. The lowlands have an adequate climate for dairy farming and agricultural production [27].

\section{Data}

In total 29 interviews were carried out in April-May 2019; Table 2 provides an overview of the participants and the role they have in the sector. As this table shows, there can be more than one participant that does similar functions on different scales or that have multiple roles. For instance, there are some that perform a double or triple role like farmers that are owners of a milk bar or farmers that can participate in the formal and informal sector at the same time by having different buyers.

\section{Results and discussion \\ Results}

The key findings of the interviews are presented here in a series of tables separated according to the type of participant (stakeholders, farmers, transporter, etc.). The first differentiation done was between stakeholders and those regarded as general actors. ${ }^{2}$ Stakeholders are the authorities, while general actors are the rest of the links in the supply chain. Table 3 includes the information from the stakeholders, Table 4 presents the information from the

Table 2 Number of participants interviewed and their roles in the milk sector

\begin{tabular}{|c|c|c|}
\hline Role & $\begin{array}{l}\text { Number of } \\
\text { interviewees }\end{array}$ & Function of each participant \\
\hline \multirow[t]{3}{*}{ Farmers } & \multirow[t]{3}{*}{7} & Big scale production farmer (180 producing cows) \\
\hline & & 3 medium-scale farmers (Own more than 5 producing cows) \\
\hline & & $\begin{array}{l}3 \text { smallholder farmers } \\
\text { ( less than } 5 \text { producing cows }\end{array}$ \\
\hline Transporter & 1 & Double role as a farmer and as a transporter between farms and the cooling tank \\
\hline \multirow{3}{*}{$\begin{array}{l}\text { Cooling tank / bulking tank } \\
\text { Do not pasteurize }\end{array}$} & \multirow[t]{3}{*}{3} & Site operator of the facilities in the cooling tank \\
\hline & & The administrator of government own cooling tanks in the county (Stakeholder) \\
\hline & & The administrator of privately own cooling tanks in the county (Stakeholder) \\
\hline $\begin{array}{l}\text { Processor /distributor } \\
\text { Pasteurize }\end{array}$ & 1 & Pasteurizes milk and delivers to milk vending machines \\
\hline Milk kiosk & 3 & Owner or salesperson of the milk kiosk that sells directly to the final consumer \\
\hline \multirow[t]{2}{*}{ Milk bar } & \multirow[t]{2}{*}{4} & $\begin{array}{l}\text { Double role as farmers and as owners of the milk bar that sells their own milk directly to the final } \\
\text { consumer }\end{array}$ \\
\hline & & Salesperson of privately own milk bar that sells directly to the final consumer \\
\hline \multirow[t]{2}{*}{ Milk vending machines } & \multirow[t]{2}{*}{3} & 2 owners of small shops that operate a milk vending machine \\
\hline & & Supervisor of a supermarket that operates a milk vending machine \\
\hline \multirow[t]{2}{*}{ Consumers } & \multirow[t]{2}{*}{5} & School girl administrator responsible for purchasing the milk for the staff and the students \\
\hline & & 4 final consumers for personal consumption \\
\hline \multirow[t]{2}{*}{ Authorities } & \multirow[t]{2}{*}{2} & $\begin{array}{l}\text { Representatives of KDB and KEBS } \\
\text { (Stakeholder) }\end{array}$ \\
\hline & & $\begin{array}{l}\text { Former chairman of Kenya Veterinary Board } \\
\text { (Stakeholder) }\end{array}$ \\
\hline
\end{tabular}
detailed interviews are not included, and the authors opted for a summary of the key findings. The anonymous interviews are available from the authors upon request. 
Table 3 Summary results of the interviews with authorities

\begin{tabular}{|c|c|c|}
\hline \multirow[t]{2}{*}{ Topic } & \multicolumn{2}{|l|}{ Stakeholders } \\
\hline & KDB and KEBS & Former chairman of Kenya Veterinary Board \\
\hline Challenges the sector faces & $\begin{array}{l}\text {-Lack of proper regulatory framework } \\
\text {-Challenges developing quality standards } \\
\text {-Costs and technical implications of complying and implementing } \\
\text { standards } \\
\text {-Lack of market access } \\
\text {-Lack of awareness on the relevance of milk safety }\end{array}$ & $\begin{array}{l}\text { - Lack of regulation of veterinary practices } \\
\text { - Milk safety hazards that affect public health like } \\
\text { the presence of contaminants as mycotoxins and } \\
\text { adulterants } \\
\text {-Unsanitary milk handling practices throughout the } \\
\text { supply chain }\end{array}$ \\
\hline $\begin{array}{l}\text { Drivers for growth of the } \\
\text { informal market }\end{array}$ & $\begin{array}{l}\text {-Milk pricing (what the consumer can afford) } \\
\text { - Compliance has no added value and is not reflected in prices } \\
\text { - Less accountability of the suppliers (no legal consequences if the } \\
\text { law is infringed) } \\
\text {-Participants do not understand that every step in the chain is a } \\
\text { control point to ensure quality }\end{array}$ & $\begin{array}{l}\text { - Lack of control on the operation of hawkers } \\
\text { - Less accountability and binding responsibilities } \\
\text {-Cheap operational costs }\end{array}$ \\
\hline
\end{tabular}

Source: Own elaboration

Table 4 Summary results of the interviews with farmers and transporters

\begin{tabular}{|c|c|c|c|c|}
\hline \multirow{3}{*}{$\begin{array}{l}\text { Topic } \\
\text { Size }\end{array}$} & \multicolumn{4}{|l|}{ Actors } \\
\hline & \multicolumn{3}{|l|}{ Farmers (7 interviewed) } & \multirow{2}{*}{$\begin{array}{l}\text { Transporter ( } 1 \text { interviewed) } \\
\text { Milk transporter and } \\
\text { smallholder farmer }\end{array}$} \\
\hline & $\begin{array}{l}\text { Big scale production } \\
\text { farmer }\end{array}$ & $\begin{array}{l}3 \text { medium scale } \\
\text { production farmers }\end{array}$ & 3 smallholder farmers & \\
\hline Production capacity & 1300-1400 L/day & 145-160 L/day & 10-20 L/day & \\
\hline $\begin{array}{l}\text { Refrigerated storage } \\
\text { capacity }\end{array}$ & Yes & $\begin{array}{l}2 \text { farmers: Yes } \\
1 \text { farmer: No }\end{array}$ & No & $\begin{array}{l}\text { No refrigerated transporta- } \\
\text { tion }\end{array}$ \\
\hline Milk selling price per litre & $50-60 \mathrm{KSH}$ & $30-36$ KSH & $30-36 \mathrm{KSH}$ & To transport milk $3 \mathrm{KSH}$ \\
\hline Main buyers & $\begin{array}{l}\text { Final consumer, i.e., banks } \\
\text { and schools }\end{array}$ & $\begin{array}{l}\text { 1.For own consumption } \\
\text { 2.Cooling tank or coopera- } \\
\text { tive } \\
\text { 3.Broker }\end{array}$ & $\begin{array}{l}\text { 1.For own consumption } \\
\text { 2.Cooling tank or coopera- } \\
\text { tive } \\
\text { 3.Broker }\end{array}$ & KCC \\
\hline Quality practices & $\begin{array}{l}\text {-Check feed quality } \\
\text {-Quality practices place } \\
\text { in situ } \\
\text {-Animals' health check } \\
\text { routinely }\end{array}$ & $\begin{array}{l}\text { 1.Cleaning of the udder } \\
\text { 2.Check regularly cow's } \\
\text { health } \\
\text { 3.Milk kept in cool condition } \\
\text { after milking either inhouse } \\
\text { or in a cooling tank }\end{array}$ & $\begin{array}{l}\text { General mention of hygiene. } \\
\text { No specific practice was } \\
\text { reference }\end{array}$ & $\begin{array}{l}\text { 1.Transports milk in an Alu- } \\
\text { minium can } \\
\text { 2.Collects milk as soon as } \\
\text { milked }\end{array}$ \\
\hline Receive training & Yes & Yes & $\begin{array}{l}\text { Yes, but not from certified } \\
\text { authority }\end{array}$ & No \\
\hline
\end{tabular}

Source: Own elaboration

farmers and producers. Table 5 encompass the information from the different selling points.

Since the focus of the case study is understanding the way the informal sector operates, those that participate mainly in the formal sector, like the milk processors, are not included in the overview shown. Each table covers the key topics that affect each of the participants in the supply chain.

Throughout all the interviews conducted milk quality and safety seem to be two concerns that all actors have in common. As Table 3 shows, the authorities emphasize that one of the main drivers for the growth of the informal market is the lack of awareness of the consumer regarding the importance of consuming safe milk. In addition, they also mention that milk pricing can be a factor that encourages the participation of the consumer in the informal sector. The implementation and maintenance of quality is an expensive endeavour that increases production costs. The added value of safe milk is not always reflected in the final milk price or in the consumers choice. Consumers with low-income need low-cost milk to be able to afford it.

Tables 4 and 5 show that all the interviewees, regardless of their size, consider that hygiene is one of the most relevant aspects to ensure quality. However, some smallholders did not have access to the correct facilities 
Table 5 Summary results of the interviews with milk kiosk, bars, and milk vending machines

\begin{tabular}{|c|c|c|c|}
\hline \multirow[t]{2}{*}{ Topic } & \multicolumn{3}{|l|}{ Participants } \\
\hline & Milk kiosks (3 interviewed) & Milk bar (4 interviewed) & Milk vending machine ( 3 interviewed) \\
\hline Milk buying price per litre & $40-50 \mathrm{KSH}$ & Not disclose & Not disclose \\
\hline Milk selling price per litre & $60 \mathrm{KSH}$ & $50-60 \mathrm{KSH}$ & $60-65 \mathrm{KSH}$ \\
\hline Supplier & $\begin{array}{l}\text { - Direct from farmers } \\
\text {-Hawkers }\end{array}$ & $\begin{array}{l}3 \text { out of } 4 \text { sourced from } \\
\text { own production } \\
1 \text { out of } 4 \text { sourced from } \\
\text { hawker }\end{array}$ & Processor \\
\hline Milk quality checks in situ & \multicolumn{3}{|c|}{$\begin{array}{l}\text {-No testing was done but they all mention trusting their suppliers } \\
\text {-Organoleptic test }\end{array}$} \\
\hline Sell raw milk & Yes & $\begin{array}{l}2 \text { out of } 4 \text { : Yes } \\
2 \text { out of } 4 \text { : No }\end{array}$ & No \\
\hline Storage with refrigeration & $\begin{array}{l}1 \text { out of } 3: \text { Yes } \\
2 \text { out of } 3: \text { No }\end{array}$ & $\begin{array}{l}2 \text { out of } 4: \text { Yes } \\
2 \text { out of } 4 \text { : No }\end{array}$ & Yes, inside the machine \\
\hline Main buyers & \multicolumn{3}{|l|}{ Final consumer } \\
\hline Quality measures in the facilities & \multicolumn{3}{|c|}{$\begin{array}{l}\text {-Hygiene } \\
\text {-Clean milk containers and measuring cups with soap and warm water } \\
\text {-Use of bleach to clean }\end{array}$} \\
\hline Attended milk handling training & No & $\begin{array}{l}1 \text { out of } 4: \text { Yes } \\
3 \text { out of } 4 \text { : No }\end{array}$ & Yes, and a license to operate from KDB \\
\hline Main problems to ensure milk quality & \multicolumn{2}{|c|}{$\begin{array}{l}\text { Not having the correct facilities like running water for proper clean- } \\
\text { ing }\end{array}$} & Problems with electricity \\
\hline
\end{tabular}

Source: Own elaboration

or public services like running water complicating hygienic handling. For transport and storage, most of the smallholder participants use plastic containers. To clean these containers the common practice is to use regular soap and water or hot water, soap, and bleach. There is no after testing to evaluate possible residues.

The system follows many routes to reach the final consumers with actors participating in both markets simultaneously, interlinking the formal and informal system at different levels. Out of all the people interviewed; only a few participants, especially those categorized as big scale in terms of production, have received adequate milk handling or quality training from certified authorities. Small and middle actors have limited knowledge of some of the main risks associated with milk. For instance, few participants have heard about mycotoxins or knew about aflatoxins in milk.

The usual selling price per litre for small farmers to cooperatives was between 30 and 36 Kenyan shilling (KSH) per litre. Processors that pasteurize the milk reported buying the raw milk at $40 \mathrm{KSH} /$ litre and selling pasteurized milk at $55 \mathrm{KSH} /$ litre. Next, the milk vending machines owners reported their selling prices at $60-65 \mathrm{KSH} /$ litre. Contrastingly, the milk kiosks and bars interviewed, that sold raw milk had a coinciding selling price of $60 \mathrm{KSH} /$ litre. Hence, the final consumers pay a very similar price for raw or pasteurized milk.
The informal milk market is the one that operates outside of the legal framework. KDB and KEBS representatives agreed that two relevant factors that directly impact the quality of the commercialized milk, (especially of unpacked raw fresh milk) are the lack of compliance in the regulation and the lack of awareness of the consumers about safety risks. The general opinion is that handling milk with hygiene is directly linked to good quality. However, the observed situation demonstrated that some of the adopted practices mainly of the informal sector reflected the lack of capacitation and training that affects the system. In addition, the lack of testing is also evident since almost none of the participants relied in certified laboratory results to ensure quality or safety of their products.

The lack of vertical integration of milk pricing is another factor that is worth mentioning. The milk bought raw or pasteurized in formal and informal places had remarkably similar prices. The cost of compliance and pasteurization is not shown in the final price, displaying they have no added value for the consumer.

\section{Discussion}

From a food safety perspective, to ensure that a certain product is safe, a systematic approach is necessary. Quality assurance requires that all the elements involved in the production comply with quality standards and that 
all the possible risks are foreshadowed and prevented [38]. Some of the risks found in the system are associated with the lack of awareness and accountability, absence of proper training, insufficient infrastructure, and milk pricing.

The actors interviewed from both types of markets highlighted the relevance that hygiene and quality have on safety. Yet, there is a lack of unification of what these terms mean or what do they encompass when applied to real life. Hygiene is a broad term that has an open interpretation. For farmers, hygiene should consider the conditions of the udder, the handler, and the container. However, some farmers especially smallholders did not have access to water which complicates and sometimes precludes the cleaning procedures.

Other sanitation problems involve the material of the containers and cleaning procedures used. Most of the smallholders use plastic containers and they clean them with soap and water or with hot water, soap, and bleach. Residues of soap and bleach can become milk pollutants and affect human health [35]. In addition, if plastic containers are not properly clean biofilms can form and become a source of microbial contamination for any milk stored in them [33]. Ensuring milk quality when there are numerous steps and a lack of control in between them is challenging especially when milk handling involves many participants that are not qualified or aware of the risks associated with their daily activities.

The aforementioned complexity of the milk chains makes traceability a challenge. Lack of accountability is reflected in the way milk goes from one actor to the other without being properly tested. Figure 1 and Table 2 show the flow of the milk market and the main actors in Kenya, exemplifying how milk exchanges follow many types of paths and there are limited control points along them. The absence of accountability is also evident by how rejected milk just gets resell but no risk analysis is done to prevent the events from reoccurring $[32,36]$. For instance, when milk from a transporter is rejected in the cooling tank; its disposal becomes their responsibility. Since their livelihood depends on this money, they sort alternative solutions like selling to hawkers that then distribute into the informal markets. These situations harm the milk safety for consumers in the informal market; as Roesel and Grace [36] stated: "what formal reject informal eats" (pp 28). Kiambi et al. [21] mention that food safety is also compromised when milk becomes scarce and the consumer especially those with low-income accepts low quality milk over nothing. Many of these risk situations could be avoided if there was more awareness of the hazards and the actors had access to reliable sources of information. In addition, this situation could be avoided if the consumption of pasteurized milk was prioritized over raw milk ensuring a more stable milk flow with prolonged shelf life that is less dependent on seasonality.

Training is a good way to create a web of informed actors [1]. As the case study shows, those participants that have had capacitation seem to include more quality measures than those who have not. For instance, the milk bar owner that mentioned going to training regularly had better handling practices when compared with the others, i.e., washing the equipment between uses, refrigerating the milk and having a veterinary certification. This was also discussed in the interviews with KEBS and KDB. They asserted that training the sellers is key since they can have a direct impact on the quality the consumers get. Some sellers that opt to act in the informal market have better prices or have more gains by compromising the quality and jeopardizing the consumer's health. Another problem regarding this issue is that even if capacitation is provided not all actors have access to it or are willing to participate for fear of retaliation or harassment from the corresponding authorities.

Another aspect that affects transversely the system is the lack of infrastructure. Infrastructure deficiencies can be categorized into four main areas: transportation, quality testing facilities, cooling facilities and selling facilities. As mention before, one of the biggest challenges the sector faces are the distance from producing to processing to selling sites and the logistics involved in getting and keeping quality milk. There are in general not adequate vehicles with refrigeration to move the milk from one place to the other. Milk that is not chilled increases the possibilities of spoilage and favours microbial growth [4, 33]. Cooling tanks have a triple function of bulking, chilling and acting as a quality control point. Nonetheless, visiting some of these facilities and witnessing how some of the tests are conducted is evident that not all locations can fully satisfy these purposes. Most of the tanks visited lacked the equipment and an adequate site for quality testing. Lastly, the selling facilities especially the milk kiosks and bars had some basic deficiencies like running water or electricity. Meaning that cleaning the containers following Best Handling Practices and refrigerating the milk was not a possibility.

Finally, milk pricing plays a pivotal role in milk safety [35]. Some actors that participate in the formal sector like the cooling tanks have fixed prices throughout the year. These situations have positive outcomes like ensuring providers a fixed income from the milk sold. On the offside, milk is impacted by seasonality, during the drought season farmers have better offers from independent brokers and divert their milk to them. For that reason, the milk flow in the tank becomes irregular and complicates having fixed selling volumes. This consequently creates 
shortages for the formal system and makes process milk more expensive having further favoured the informal system, this situation was also mentioned by Nyokabi et al. [32]. Another situation regarding milk pricing that favourites the informal market is the difference between milk that goes through short versus long supply chains. When farmers sell their milk to cooling tanks, they get 30 to $36 \mathrm{KSH}$ per litre. After pasteurization, that milk reaches the market with a price of 60 to $65 \mathrm{KSH}$ per litre. In comparison, the farmers that sell raw milk directly to final consumers get 50 to $60 \mathrm{KSH}$ per litre. Consequently, raw milk and pasteurized milk have similar prices. It is understandable why processors complained about having to pay extra fees for getting licenses or having to establish extra quality tests to comply with the regulations that are costly if they do not have the added value reflected on the selling price since the consumers are not willing to pay extra.

\section{Conclusions}

The purpose of this case study has been to provide information about food safety along an informal dairy supply chain. The informal dairy sector is normally associated with low-quality milk and food safety risks. In the case study conducted the stakeholders stated that these assumptions are linked to several factors: first, the lack of contact and control from the sanitary and health authorities; followed by the lack of awareness regarding milk safety from both consumers and the different supply chain participants; and lastly, the poor operating conditions the informal market has.

In addition, some risks recognized with the case study were the overall lack of hygiene, accountability and infrastructure in the entire supply chain. Another interesting conclusion was that the milk prices the final consumer pays do not reflect the added value that pasteurization offers in terms of milk quality and safety. Raw milk and pasteurized unpacked milk tend to have very similar prices that are mainly dependable on the vendor.

Overall, the review of the safety issues related to the consumption of unpasteurized milk indicates that there are contaminants that are not eliminated by boiling milk; however, several of these can be improved with better handling along the supply chain. A key aspect of the reform of Kenya's informal dairy market was the formalisation of raw milk traders and the training to improve the hygiene and safety of their operations. This needs to be reinforced by the authorities. Interestingly, the Government of Kenya announced in February 2021 the inauguration of a National Dairy Laboratory to conduct quality surveillance and safety compliance. This activity needs to be completed with further training to the participants of the informal supply chain.
The value of the results is meaningful, because SSA countries see the reform of the Kenyan dairy sector as an example and a way to progress their dairy sector. If the SSA countries want to legalise their informal sector they need to consider all the aspects, benefits, and hurdles that this sector provides, and the challenges introduced by the Kenyan reform and its compliance.

\section{Annex}

Base interview Template.

\begin{tabular}{ll}
\hline Name & Age \\
\hline Location & \\
Occupation: & Unit \\
Milk buying price & Unit \\
Milk selling price & Unit \\
Minimum buying unit & Unit \\
Minimum selling unit & \\
To producer/sellers \& buyers & \\
Why do you participate in the dairy sector? & \\
How did you become involved? & \\
Since when are you involved? & \\
To sellers or producers & \\
How many litters can you produce daily? & \\
Who are your main buyers? & \\
What practices do you have that assure milk quality? & \\
What happens when one of your animals get sick? & \\
Have you had any training in milk handling? & \\
To buyers/ consumers & \\
How often do you buy milk? & \\
What do you do with that milk? & \\
How do you store the milk? & \\
How do you check the quality of the milk you are buying? \\
What happens if the milk you bought has poor quality? \\
Where do you sell?
\end{tabular}

Source: Own elaboration

\section{Abbreviations}

AFB1: Aflatoxin B1; AFM1: Aflatoxin M1; CAP: Chapter; GDP: Gross Domestic Product; JKUAT: Jomo Kenyatta University of Agriculture and Technology; KDB: Kenya Dairy Board; KEBS: Kenyan Bureau of Standards; KSH: Kenyan shilling; New KCC: New Kenya Co-operative Creameries LTD; SDP: Smallholder Dairy Project; SSA: Sub-Saharan Africa; STEC: Shiga-toxin-producing Escherichia coli.

\section{Acknowledgements}

This paper is based on work done as part of the MSc Thesis in Food Security by Ms. Zavala-Nacul (University of Edinburgh) and from the Dfid-ESRC project 
"Assessing contribution of Dairy Sector to Economic Growth and Food Security in Malawi" (ES/J009202/1). Any opinions expressed within the paper are entirely those of the authors.

\section{Authors' contributions}

$\mathrm{HZ}-\mathrm{N}$ contributed to the design of the study, carried out the fieldwork and wrote the first draft; CR-G contributed to the design of the study, supervised the study, contributed to the organisation and writing of the paper. Both authors read and approved the final manuscript.

\section{Funding}

Economic and Social Research Council, Assessing contribution of Dairy Sector to Economic Growth, Cesar Revoredo-Giha, Food Security in Malawi, Cesar Revoredo-Giha.

\section{Availability of data and materials}

The data sets during and/or analysed during the current study available from the corresponding author on reasonable request.

\section{Code availability}

Not applicable.

\section{Declarations}

\section{Ethics approval and consent to participate}

The authors declare that there is no conflict of interests financial or non-financial.

\section{Consent for publication}

Both authors give consent for the publication of this paper.

\section{Competing interests}

The authors have no relevant financial or non-financial interests to disclose.

\section{Author details}

${ }^{1}$ Independent Food Security Consultant, Mexico City, Mexico. ${ }^{2}$ Department of Rural Economy, Environment and Society, Scotland's Rural College (SRUC), King's Buildings, Edinburgh EH9 3JG, UK.

Received: 21 June 2021 Accepted: 19 November 2021 Published online: 04 February 2022

\section{References}

1. Alonso S, et al. Beyond food safety: Socio-economic effects of training informal dairy vendors in Kenya. Glob Food Sec. 2018;18:86-92. https:// doi.org/10.1016/j.gfs.2018.08.006.

2. Antonioli F, Santeramo FG. On policy interventions and vertical price transmission: the italian milk supply chain case. J Agric Resour Econ. 2021. https://doi.org/10.22004/ag.econ.310533.

3. Anyango $\mathrm{G}$, et al. A survey of aflatoxin $\mathrm{M} 1$ contamination in raw milk produced in urban and peri-urban areas of Kisumu County, Kenya. Infect Ecol Epidemiol. 2018;8(1):1-10. https://doi.org/10.1080/20008686.2018. 1547094.

4. Artursson K, et al. International Journal of Food Microbiology Foodborne pathogens in unpasteurized milk in Sweden. Int J Food Microbiol. 2018;284:120-7. https://doi.org/10.1016/j.ijfoodmicro.2018.05.015.

5. Azad T, Ahmed S. Common milk adulteration and their detection techniques. Int J Food Contam. 2016;3(1):1-9. https://doi.org/10.1186/ s40550-016-0045-3.

6. Banik SK, Das K, Uddin A. Microbiological quality analysis of raw, pasteurized, UHT milk samples collected from different locations in Bangladesh assay. Stamford J Microbiol. 2014;4(1):5-8. https://doi.org/10.3329/sjm. v4i1.22753.

7. Bartoszewicz M, Hansen BM, Swiecicka I. The members of the Bacillus cereus group are commonly present contaminants of fresh and heattreated milk. Food Microbiol. 2008;25(4):588-96. https://doi.org/10.1016/j. fm.2008.02.001.
8. Bosire CK, et al. Trends and spatial variation in water and land footprints of meat and milk production systems in Kenya. Agr Ecosyst Environ. 2015;205:36-47. https://doi.org/10.1016/j.agee.2015.02.015.

9. Bryman A. Social research methods. 5th ed. Oxford: Oxford University Press; 2015.

10. Coppock, R. W., Christian, R. G., \& Jacobsen, B. J. (2018). Aflatoxins. In: Veterinary toxicology: basic and clinical principles, 3rd edition. Elsevier Inc. https://doi.org/10.1016/B978-0-12-811410-0.00069-6

11. Enquebaher T, Siv S, Knut R, Taran S, Judith AN. Staphylococcus aureus and other Staphylococcus species in milk and milk products from Tigray region, Northern Ethiopia. Afr J Food Sci. 2015;9(12):567-76. https://doi. org/10.5897/ajfs2015.1373.

12. FAOSTAT (2019) Livestock Primary Data. http://www.fao.org/faostat/en/\# data/QL. Accessed 2 Aug 2019.

13. FEWS NET (2019) 'Kenya Food Security Outlook Update, April 2019'. Kenya USAID. https://reliefweb.int/report/kenya/kenya-food-security-outlookupdate-april-2019. Accessed 26 July 2019.

14. Huang Y, Flint SH, Palmer JS. Bacillus cereus spores and toxins-the potential role of biofilms. Food Microbiol. 2020. https://doi.org/10.1016/j. fm.2020.103493.

15. Kaitibie, S. et al. (2009) Influence pathways and economic impacts of policy change in the Kenyan dairy sector, Research Report 15. Kenya. ILRI

16. Kaitibie $S$, et al. Kenyan dairy policy change: influence pathways and economic impacts. World Dev. 2010;38(10):1494-505.

17. Kang'ethe EK, et al. Investigation of the risk of consuming marketed milk with antimicrobial residues in Kenya. Food Control. 2005;16(4):349-55. https://doi.org/10.1016/j.foodcont.2004.03.015.

18. KEBS (2019) Online Catalogue. Kenya Bureau of Standards Online Catalogue. http://onlinecatalogue.kebs.org/webquery.dll?v20=1\&v22=2F. Accessed 26 July 2019.

19. Kenya Agricultural Research Institute (2012) Food Security Report. IFPRI, Washington DC. http://www.foodsecurityportal.org/kenya/food-secur ity-report-prepared-kenya-agricultural-research-institute. Accessed 3 Aug 2019.

20. Kiambi S, et al. Mapping Nairobi's dairy food system: an essential analysis for policy, industry and research. Agric Syst. 2018;167:47-60. https://doi. org/10.1016/j.agsy.2018.08.007.

21. Kiambi S, et al. Investigation of the governance structure of the Nairobi dairy value chain and its influence on food safety. Prev Vet Med. 2020. https://doi.org/10.1016/j.prevetmed.2020.105009.

22. Kiambu County webpage (2021) About us. https://kiambu.go.ke/aboutus/. Accessed 13 Oct 2021.

23. Kurwijila LR. Hygienic milk handling, processing and marketing: reference guide for training and certification of small-scale milk traders in Eastern Africa. Nairobi: ILRl; 2006.

24. Lindahl JF, Kagera IN, Grace D. Aflatoxin M 1 levels in different marketed milk products in Nairobi Kenya. Mycotoxin Rese. 2018;34:289-95. https:// doi.org/10.1007/s12550-018-0323-4.

25. Liu, S.S., (2018). Investigation and Identification of Physical Contaminants in Food. Food Safety Magazine. https://www.foodsafetymagazine.com/ magazine-archive1/junejuly-2018/investigation-and-identification-ofphysical-contaminants-in-food/. Accessed 1 Apri1 2019.

26. Macdonald LE, Brett J, Kelton D, Majowicz SE, Snedeker K, Sargeant JM. A systematic review and meta-analysis of the effects of pasteurization on milk vitamins, and evidence for raw milk consumption and other healthrelated outcomes. J Food Prot. 2011;74(11):1814-32. https://doi.org/10. 4315/0362-028X.JFP-10-269.

27. Murang'a County webpage (2021) About us. https://muranga.go.ke/? page_id=3130. Accessed 13 Oct 2021.

28. Muriuki, H. G. (2003) 'Milk and dairy products, post-harvest losses and food safety in Sub-Saharan Africa and the Near East. A review of small scale dairy sector Kenya',Kenya. FAO. http://www.fao.org/fileadmin/templ ates/ags/docs/dairy/P1assessmentkenya.pdf. Accesses 22 April 2019.

29. Mwere, D., (2019). Tough times ahead for dairy farmers. Daily Nation. https://www.nation.co.ke/news/New-proposed-dairy-industry-regulation s-/1056-5037548-073yko/index.html. Accesses 25 July 2019.

30. Nyariki DM. Impacts of policy reforms on the livestock industry in Kenya: The case of the dairy sector. Livest Res Rural Dev. 2009;21(10):1-12.

31. Nyokabi S, Luning PA, de Boer IJM, Korir L, Muunda E, Bebe BO, Lindahl J, Bett B, Oosting SJ. Milk quality and hygiene: Knowledge, attitudes and 
practices of smallholder dairy farmers in central Kenya. Food Control. 2021;130:108303.

32. Nyokabi, S. et al. (2018) The Kenyan dairy sector: stakeholder roles and relationships and their impact on milk quality. European IFSA Symposium, Chania.

33. Oliver SP, et al. Food safety hazards associated with consumption of raw milk. Foodborne Pathog Dis. 2009;6(7):793-806. https://doi.org/10.1089/ fpd.2009.0302.

34. Omore, A. et al. (2002) 'Analysis of Milk-Borne Public Health Risks in Milk Markets in Kenya', In: Annual Symposium of the Animal Production Society of Kenya, 9-10 May. Naivasha, Kenya

35. Ondieki GK, et al. Antimicrobial residues and compositional quality of informally marketed raw cow milk, Lamu West Sub-County, Kenya, 2015 Pan African Med J. 2017;28(Supp 1):1-6. https://doi.org/10.11604/pamj. supp.2017.28.1.9279.

36. Roesel K, Grace D. Food safety and informal markets animal products in sub-Saharan Africa, London. New York: Routledge; 2015.

37. Smigic N, et al. Implication of food safety measures on microbiological quality of raw and pasteurized milk. Food Control. 2012;25(2):728-31. https://doi.org/10.1016/j.foodcont.2011.12.022.

38. Ssemukasa E, Kearney J. Health and food safety concerns of early dietary introduction of unmodified cow milk to infants in developing countries. Afr J Food Agric Nutr Dev. 2014;14(1):8504-17.

39. Susanty A, Bakhtiar A, Jie F, Muthi M. The empirical model of trust, loyalty, and business performance of the dairy milk supply chain: a comparative study. Br Food J. 2017;119(12):2765-87. https://doi.org/10.1108/ BFJ-10-2016-0462.

40. Thorpe, W. et al. (2000) 'Dairy development in Kenya: the past, the present and the future.' In: Annual Symposium of the Animal Production Society of Kenya, 22-23 May. Nairobi, Kenya

41. Vidalon, D., (2014). Danone buys 40 pct stake in Kenya's Brookside. Reuters 2 minute read. https://www.reuters.com/article/danone-brook side/danone-buys-40-pct-stake-in-kenyas-brookside-idUSP6N0O900J20 140718. Accessed 25 July 2019.

42. Wanjala G, et al. Microbiological quality and safety of raw and pasteurized milk marketed in and around Nairobi region. AJFAND. 2017;17(1):1151832. https://doi.org/10.18697/ajfand.77.15320.

43. Yang Y, Huisman W, Hettinga KA, Zhang L, van Ruth SM. The Chinese milk supply chain: a fraud perspective. Food Control. 2020;113(January): 107211. https://doi.org/10.1016/j.foodcont.2020.107211.

44. Yin R. Case study research design and methods. London: SAGE; 2002.

\section{Publisher's Note}

Springer Nature remains neutral with regard to jurisdictional claims in pub-

lished maps and institutional affiliations.

- fast, convenient online submission

- thorough peer review by experienced researchers in your field

- rapid publication on acceptance

- support for research data, including large and complex data types

- gold Open Access which fosters wider collaboration and increased citations

- maximum visibility for your research: over $100 \mathrm{M}$ website views per year

At BMC, research is always in progress.

Learn more biomedcentral.com/submissions 